\title{
REVISITING THE REGISTRATION OF EUROPEAN CITIZENS' INITIATIVES: THE EVOLUTION OF THE LEGAL ADMISSIBILITY TEST
}

Anastasia Karatzia*

\begin{abstract}
According to the main element of the European Citizens' Initiative (ECI) legal admissibility test set out in Regulation 211/2011, a proposed ECI cannot collect signatures of support if it 'manifestly falls outside the framework of the Commission's powers to submit a proposal for a legal act of the Union for the purpose of implementing the Treaties.' This contribution argues that the interpretation and application ECI legal admissibility test have developed since the early years of the ECI's operation, largely due to the CJEU's intervention in ECIcases. It analyses the procedural and substantive changes to the test in light of the relevant litigation and the ongoing reform of the ECI's legal framework. It illustrates that certain contested procedural aspects of the ECI legal admissibility test have been resolved, while the scope of the ECI has been extended to allow Initiatives in the field of international agreements. The article explores the effects of these developments on current and future ECI practice, including the possibility to bring an ECI in the context of the Brexit EU-UK negotiations.
\end{abstract}

Keywords: Democratic Participation, Court of Justice of the European Union, International Agreements, TTIP, Brexit, European Commission

\section{INTRODUCTION}

Since its inception, the European Citizens' Initiative (ECI) has faced numerous criticisms, not least due to its 'legal admissibility test', which is a prerequisite for a proposed Initiative to be registered as an ECI and start collecting signatures. The test exists mainly to filter out proposed Initiatives that are legally unattainable and thus cannot be acted upon even if they collect the necessary number of signatures. According to the only criterion of the test that has been used so far to reject proposed Initiatives, the Commission will not register an Initiative if the proposal 'falls manifestly outside the scope of the Commission's powers to submit a proposal for a legal act of the Union for the purpose of implementing the Treaties'. ${ }^{1}$ Overall, in the six years of the ECI's life, the Commission has refused registration to 22 out of 48 proposed Initiatives. The relatively high number of rejections led commentators, ECI

\footnotetext{
* Lecturer in Law, School of Law, University of Essex. I would like to thank Professor Kenneth Armstrong, as well as Dr. Federica Violi, Dr. Onyeka Osuji, Professor Theodore Konstadinides, and the reviewers for their valuable comments and feedback. Part of this research was conducted at the University of Liverpool with the kind support of the School of Law International Visiting Research Fellowship Programme. All errors are mine. ${ }^{1}$ Article 4(2)(b) of Regulation 211/2011 the citizens' initiative [2011] OJ L 65/1 (hereinafter 'ECI Regulation'). See Article 4(2) of that Regulation for all the criteria of the legal admissibility test.
} 
organisers, and civil society organisations to criticise, in the past, the Commission's interpretation and application of Article 4(2)(b) of the legal admissibility test.

Even the Commission itself has identified difficulties faced by citizens when trying to propose legally admissible initiatives, as stipulated in the recently published Commission's Second Report on the ECI Regulation. ${ }^{2}$ When looking at the statistics in the Report, however, one thing, among others, strikes the attention of the reader: the decrease in the number of rejections to proposed Initiatives from 2012 until 2018. In the first three years of the ECI's existence (2012-2015), the Commission rejected 20 Initiatives. Between 2015 and 2018, that number decreased to only two. ${ }^{3}$ The difference between the two numbers prompts an inquiry as to the reasons behind the decrease. Surely, one reason is that the number of requests for registration has also decreased since 2015, from 51 between 2012 and 2015, to merely 19 between 2015 and 2018. An additional reason, however, may be that the ECI legal admissibility test itself has developed and changed in comparison to the first years of the ECI's operation.

This article seeks to explore the evolution of the ECI legal admissibility test. It argues that the Court of Justice of the European Union (CJEU) in ECI-related cases has played a primary role in the development of the test, not only by clarifying aspects of the test, but also by triggering certain changes to the Commission's approach towards the registration of proposed Initiatives. In particular, the contribution identifies the evolution of the test by analysing the ECI-judgments delivered by the CJEU and exploring the impact of those judgments on the interpretation and application of the legal admissibility test by the Commission in recent registration decisions.

The article argues that the evolution of the ECI's legal admissibility test can be seen both in procedural and in substantive terms. With regard to procedure, the nature of the test has become more flexible by allowing inter alia the registration of only part of a proposed Initiative. This means that, contrary to the Commission's initial approach, an Initiative putting forward multiple proposals can be registered even when not all its proposals are compliant with the Article 4(2)(b) of the ECI Regulation. With regard to the substantive aspects of the test, the scope of application of the ECI has expanded in comparison to the early interpretation of the legal admissibility test by the Commission. It now includes proposals on the conclusion of international (trade) agreements, where direct citizens' participation has traditionally been limited. The article explains how the CJEU judgments on the ECI-cases have led to these changes.

Nevertheless, the discussion does not take at face value the changes to the ECI's legal admissibility test. Instead, it contrasts the potential that is offered in principle by the developments to the ECI's admissibility test, with the practical limitations of these developments, including those characterising the possibility to influence EU actions through

\footnotetext{
${ }^{2}$ Report from the Commission to the European Parliament and the Council on the application of Regulation (EU) No 211/2011 on the citizens' initiative, Brussels, 28 March 2018, COM(2018) 157 final p 2 (hereinafter 2018 ECI Report).

${ }^{3} 2018$ ECI Report (n 2) p 3.
} 
an ECI. In this sense, it identifies the effects of the ECI registration's evolution on current and future ECI practice.

The article begins with an overview of the relationship between the legal admissibility test and the ECI as a participatory mechanism (Section II). This should serve both as an aidememoire for those familiar with the ECI, and as an introduction to the topic for those who are not. It then analyses the evolution of the ECI legal admissibility test from two perspectives. Firstly, it discusses the impact of the CJEU's ECI-judgments on certain procedural aspects of the ECI legal admissibility test (Section III). As will be seen, the CJEU has attempted to clarify aspects of the legal admissibility test, such as the duties of the Commission and the ECI organisers when reviewing and submitting ECIs respectively, and the possibility for partial registration of an ECI. The discussion identifies the potential implications of this body of litigation by explaining the impact of the relevant judgments on the Commission's recent registration decisions, but also on the Commission's Proposal for a New ECI Regulation, which attempts to codify some of the recent changes to the legal admissibility test. ${ }^{4}$

Secondly, the article examines the impact of the CJEU judgments on the ECI's substantive aspects. It argues that the developments arising from the case law in this regard (e.g. on the type of actions that citizens can propose through an ECI) lead to a positive extension of the ECI's legal scope (Section IV). Going beyond an exploration of the case law as such, the article attempts to evaluate these advancements in the ECI's registration process by considering examples of ECIs in practice, and reflecting on the possible future use of the ECI in the context of International Agreements, taking Brexit as an example at hand.

Through the analysis of the procedural and substantive changes to the ECI legal admissibility test, the contribution aims to identify whether the ECI's legal admissibility stage has changed to such an extent that it can strengthen the ECI as a mechanism for EU citizens to express their voice and request legislative or policy action in areas as contested as - for instance - the Brexit negotiations. By doing so, the analysis contributes to the current literature on the ECI, which is currently missing an overall assessment of the ECI's admissibility test encompassing all the Court judgments and their influence on the Commission's approach and the future of the ECI. In the early stages of the ECI, the legal admissibility test had attracted the attention of scholars who attempted to map the Commission's approach to the registration of proposed Initiatives. ${ }^{5}$ Since then, academic commentary on the registration of the ECI has focused

\footnotetext{
${ }^{4}$ Proposal for a Regulation of the European Parliament and of the Council on the European citizens' initiative, Brussels 13 September 2017, COM(2017) 482 final (hereinafter 'New ECI Regulation Proposal'). The Proposal was accompanied by a Commission Staff Working Document explaining the outcome of the review process and the problems identified with the current ECI legal framework: Commission Staff Working Document Accompanying the Document Proposal for a Regulation of the European Parliament and the Council on the European citizens' initiative, Brussels 13 September 2017, SWD(2017) 294 final.
}

\footnotetext{
${ }^{5}$ See, for example A Karatzia, 'The European Citizens' Initiative in practice: Legal Admissibility Concerns' (2015) EL Rev 509 and J Organ, 'Decommissioning Direct Democracy?' (2014) 10 EuConst 422.
} 
largely on individual ECI-cases or on a discussion of the judgments delivered by the General Court vis-à-vis the objectives of the ECI. ${ }^{6}$

Against this background, the current article aims to provide a more in-depth, and up-to-date exploration of a particular aspect of the ECI, namely the application of Article 4(2)(b). Moreover, it aims to become a point for reflection on the future of the ECI and particularly on the Commission's new proposals relating to the ECI admissibility test, which has not attracted the attention of the literature so far. In this way, the article constitutes a timely and original analysis of the ECI legal admissibility test, which considers all the relevant CJEU case law, and updates previous research on the subject.

Ultimately, this contribution calls for a nuanced response to the evolution of the ECI's legal admissibility test (Section V). It argues that the well-known shortcomings of the ECI as a means to influence legislative action at the EU level, as well as the risk of an overlyformalised codification of recent changes, call for caution when painting an overly rosy picture of the ECI's registration stage in comparison with past practice. Potential ECI organisers, ECI stakeholders, and those simply interested in new channels of political participation in the EU, might wish to consider this message when forming their opinion on the nature and potential of the ECI as a mechanism for democratic participation.

\section{THE RELEVANCE OF THE LEGAL ADMISSIBILITY TEST TO THE ECI AS A PARTICIPATORY MECHANISM}

For readers unfamiliar with the topic, the ECI is a participatory mechanism introduced by the Treaty of Lisbon. It allows EU citizens to request the Commission to consider an idea as a possible basis for a legislative proposal. It has been in existence since 2012, and its legal framework consists of Article 11(4) TEU, 24 TFEU, and Regulation 211/2011 (the ECI Regulation), which sets out a detailed procedure for bringing an ECI. The organisers of an ECI have one year to collect one million signatures from seven EU Member States supporting their idea in order for it to be considered by the Commission, which ultimately has the discretion as to how to respond. ${ }^{7}$ Since 2012, 48 ECI campaigns took place, on topics ranging from the environment and education to migration and the eurozone crisis. ${ }^{8}$ Out of those, four

\footnotetext{
${ }^{6}$ The most recent contribution on this topic discusses each judgment individually and was written prior to the ECJ judgment in the case of Anagnostakis, and before the General Court's judgment in One of Us, see M Inglese, 'Recent Trends in European Citizens' Initiatives: The General Court Case Law and the Commission's Practice' (2018) 24(2) EPL 335. Other recent contributions on the ECI which, however, focus mainly on the follow-up stage of the process, include: N Vogiatzis, 'Between discretion and control: Reflections on the institutional position of the Commission within the European citizens' initiative process.' (2017) 23(3-4) ELJ 250; J Organ, 'EU Citizen Participation, Openness and the European Citizens Initiative: The TTIP Legacy' (2017) 54 CMLRev 1713.

${ }^{7}$ The CJEU recently ruled, for the first time, in a case challenging the Commission's discretion to respond to an ECI, see One of Us and Others $v$ Commission, T-561/14, ECLI:EU:T:2018:210 (hereinafter One of Us), discussed below in Section III.

${ }^{8}$ For examples of campaigns, and information on rejected Initiative proposals, the reader is directed to the dedicated website on the ECI, accessible at: 〈http://ec.europa.eu/citizens-initiative/public/welcome〉
} 
managed to reach the one million signatures, with questionable results as to their effect in triggering actual legislative or policy change at the EU level. ${ }^{9}$

In its few years of life, the ECI Regulation has been subject to extensive criticism for being overly burdensome and non-user-friendly. Voices of dissatisfaction coming, among others, from the European Parliament and from civil society organisations, led to a process of review of the instrument by the Commission which has been ongoing since $2015 .{ }^{10}$ In September 2017, the Commission published a proposal for a New ECI Regulation (hereinafter 'New ECI Regulation Proposal') after the publication of its own studies and a round of public consultation. ${ }^{11}$ According to the Commission, the amendments that need to be made in the ECI's legal framework are so substantial and fundamental that mandate the repeal and replacement of the existing ECI Regulation 'in the interest of clarity for citizens and organisers'. ${ }^{12}$ The New ECI Regulation Proposal has passed by the hands of the European Parliament, and specifically the Committee on Constitutional Affairs (AFCO) which tabled its Draft Report in March 2018. The Report was voted in plenary in July 2018 and will formulate the basis for the first round of negotiations with the Council. ${ }^{13}$ The inclusion of the ECI's revision process in the Joint Declaration on the EU's legislative priorities for 20182019 indicates that the revision is on course to be completed before the 2019 European Parliament elections. ${ }^{14}$ This article returns to the New ECI Regulation Proposal later on, to evaluate the proposed modifications to the ECI legal admissibility test. For now, the subsequent analysis focuses on the operation of the ECI under the current legal framework.

\footnotetext{
${ }^{9}$ See the ECIs 'Right2Water', 'One of Us', 'Stop Vivisection', and 'Ban Glyphosate'. A fifth ECI, namely 'Minority SafePack' has stated that it has reached the signatures but the validation process is still ongoing. On the follow-up of successfully submitted ECI campaigns see A Karatzia 'The European Citizens' Initiative and the EU Institutional balance: on Realism and the Possibilities of Affecting EU Lawmaking' (2017) 54(1) CMLRev 177; N Vogiatzis (n 6); M Conrad et al (eds), Bridging the Gap? Opportunities and Constraints of the European Citizens' Initiative (Nomos 2016). For literature from a political side perspective highlighting other positive outcomes of the ECI, such as the formation of political public spheres, see J Greenwood and K Tuokko 'The European Citizens' Initiative: the territorial extension of a European political public sphere?' (2017) 18(2) European Politics and Society 166.

${ }^{10}$ European Parliament Resolution of 28 October 2015 on the European Citizens' Initiative (P8_TA(2015)0382).

${ }^{11}$ A summary of the Commission's review process and all relevant documents are accessible at: $<$ http://ec.europa.eu/citizens-initiative/public/regulation-review>.

${ }^{12}$ New ECI Regulation Proposal (n 4) p 6.

${ }^{13}$ AFCO Draft Report on the proposal for a regulation of the European Parliament and of the Council on the European citizens' initiative (COM(2017)0482 - C8-0308/2017 - 2017/0220(COD)) 9 March 2018 (hereinafter AFCO Draft Report); European Parliament Report on the proposal for a regulation of the European Parliament and of the Council on the European citizens' initiative (hereinafter EP ECI Report 2018) (COM(2017)0482 C8-0308/2017 - 2017/0220(COD))

${ }^{14}$ European Commission, 'Joint Declaration on the EU's legislative priorities for 2018-19' available at: $<$ https://ec.europa.eu/commission/sites/beta-political/files/joint-declaration-eu-legislative-priorities-201819_en.pdf > . Point 7 mentions that legislative priority will be given to: 'Further developing the democratic legitimacy at EU level, by improving the functioning of the European Citizens' Initiative and by increasing transparency in the financing of political parties'.
} 
One of the main criticisms of the ECI is that it imposes a strict legal admissibility test for those wishing to register with the Commission a proposal for an Initiative. ${ }^{15}$ In order to submit a proposed Initiative with the Commission for registration, the organisers are required to provide the title, subject matter, and objectives of the proposed ECI, to stipulate the Treaty provisions they consider relevant for their proposal, and to give some personal details of themselves and all of the sources of funding for the ECI at the time of registration. ${ }^{16}$ The organisers can also provide an Annex to their registration form with additional information on the subject, objectives, and background to the proposed ECI, and a draft act, if they wish to do so.

Upon receiving the above information, the Commission then goes on to check whether the ECI's citizens' committee is formed and designed in accordance with the ECI Regulation ${ }^{17}$, and if the proposed Initiative complies with the so-called 'legal admissibility test' which consists of three criteria. In particular an Initiative will not be registered if it 'manifestly falls outside the framework of the Commission's powers to submit a proposal for a legal act of the Union for the purpose of implementing the Treaties ${ }^{18}$, if it is 'manifestly abusive, frivolous or vexatious" ${ }^{19}$ or "manifestly contrary to the values of the Union as set out in Article 2 TEU' ${ }^{20}$ If the Commission refuses to register an ECI, it is obliged under Article 4(3) of the ECI Regulation to inform the organisers of the reasons for such refusal and the channels through which the Commission's decision can be challenged. ${ }^{21}$

The interpretation and application of the ECI's legal admissibility test by the Commission have been the subject of analysis and discussion from the very early stages of the ECI Regulation and well into the first few years of the ECI's operation. ECI stakeholders, as well as academics, have often argued that the test is an obstacle to the effectiveness of the ECI as a participatory instrument. For instance, the Commission has been criticised for applying the Article 4(2)(b) test in an overly-legalistic manner which limits the ability of citizens to influence the EU legislative agenda. ${ }^{22}$ Civil society has been advocating for reforms to ensure 'the broadest possible' definition of the ECI's scope ${ }^{23}$, and even the Commission itself has expressed the view that 'the registration phase remains one of the main challenges in the implementation of the ECI instrument. ${ }^{24}$

\footnotetext{
${ }^{15}$ See, for example J Organ (n 15). For an overview of the criticisms, see A Karatzia (n 5).

${ }^{16}$ Annex II to the ECI Regulation.

${ }^{17}$ Article 4(2)(a) and 3(2) of the ECI Regulation.

${ }^{18}$ Article 4(2)(b) of the ECI Regulation.

${ }^{19}$ Article 4(2)(c) of the ECI Regulation.

${ }^{20}$ Article 4(2)(d) of the ECI Regulation.

${ }^{21}$ The Commission Decisions refusing registration to proposed Initiatives, are available at: $<$ http://ec.europa.eu/citizens-initiative/public/initiatives/non-registered>.

22 J Organ (n 5) 435-439.

${ }^{23}$ ECI Campaign, '9 Ways to Improve the Commission's ECI Revision Proposal' 5 April 2018, available at: <http://www.citizens-initiative.eu/9-ways-improve-commissions-eci-revision-proposal/>.

${ }^{24}$ Commission Staff Working Document (n 4) p 20.
} 
Organisers of rejected ECIs have expressed doubts as to the willingness of the Commission to encourage the use of ECIs, ${ }^{25}$ while six of them chose to challenge the Commission's rejections before the CJEU. The General Court has delivered a judgment in all of these cases, which concerned Commission Decisions to reject initiatives between 2012 and 2014. ${ }^{26}$ Three of the cases were appealed, giving the opportunity to the ECJ in the case of Anagnostakis to look into the ECI's legal framework for the first time since it was laid down the Treaty of Lisbon. $^{27}$ The General Court has also recently delivered its judgment in the case of One of Us, which is not directly related to the legal admissibility stage of the ECI but instead concerns the Commission's discretion at the final stages of an ECI. Taken together, the judgments create an entirely new body of litigation vis-à-vis citizens' participation at the EU level and clarify certain aspects of the ECI Regulation on which organisers and the Commission did not see eye to eye. This holds true notwithstanding that the CJEU found for the Commission in all but two of the cases.

Against this background, the subsequent analysis (Section III) focuses on recent clarifications and changes to the legal admissibility test, which have resulted both from the abovementioned litigation challenging the Commission's refusal to register proposed Initiatives, and from consequent modifications to the Commission's own approach to reviewing Initiative proposals. It will be argued that the CJEU has shed light on certain procedural aspects of the ECI's legal admissibility test which were, until now, debatable. It will also be shown that the CJEU's judgments have had an impact on the Commission's approach even where the CJEU did not rule precisely on a particular issue (esp. the partial registration of ECIs).

The discussion on the procedural aspects of the registration process will be followed by an exploration of the substantive changes that have resulted from the CJEU judgments (Section IV). Put together, the developments to the ECI, which have resulted from the contribution of the CJEU to procedural and substantive elements of the ECI's registration stage, illustrate how the ECI legal admissibility test has evolved since the initial stages of the ECI's life. In principle, this evolution should have positive effects to the registration of proposed ECIs, and

\footnotetext{
${ }^{25}$ See B Constantini, 'Reply to the Ombudsman's own Inquiry on the ECI', available at <http://www.ombudsman.europa.eu/en/press/release.faces/en/53306/html.bookmark> and A Karatzia (n 5).

${ }^{26}$ See Efler and Others $v$ Commission, T-754/14, ECLI:EU:T:2017:323 (hereinafter Efler); Costantini and Others v Commission, T-44/14, ECLI:EU:T:2016:223 (hereinafter Constantini); Minority SafePack v Commission, T-646/13, ECLI:EU:T:2017:59 (hereinafter Minority SafePack); Anagnostakis v Commission, T450/12, ECLI:EU:T:2015:739 (appealed in Anagnostakis v Commission, C-589/15 P, ECLI:EU:C:2017:663) (hereinafter Anagnostakis); HB and Others v Commission, T-361/14, ECLI:EU:T:2017:252 (appealed in HB and Others v Commission, C-336/17 P, ECLI:EU:C:2018:74); Izsák and Dabis v Commission, T-529/13, ECLI:EU:T:2016:282 (hereinafter Izsák and Dabis, an pending judgment on appeal in Izsák and Dabis v Commission C-420/16 P). It is also worth mentioning the case of Hungary v Commission, Case T50/16, which was a challenge by a Member State against the Commission for the registration of an Initiative proposing the enforcement of the rule of law in the EU. The case was withdrawn. It should also be noted from the outside that this contribution will not deal with the assessment by the CJEU of the actual legal bases suggested by organisers, i.e. on whether the Commission rightly or wrongly decided that a Treaty provision is not suitable as a legal basis for a specific Initiative.

${ }^{27}$ These are the Anagnostakis, HB and Others $v$ Commission, and Izsák and Dabis cases.
} 
particularly to the width of the substance of proposals that can be registered by the Commission. Whether these positive effects are reflected, or can be reflected, in practice is discussed throughout the analysis.

\section{CLARIFYING PROCEDURAL ASPECTS OF THE ECI'S REGISTRATION STAGE}

The judgments of the CJEU on the cases challenging the Commission's decisions to reject proposed Initiatives allow us to identify the contribution of this stream of litigation to the development of the ECI. ${ }^{28}$ It would be an exaggeration to say that the CJEU's case law has been transformative for all the applicants. In fact, as mentioned above, the Court ruled in favour of ECI organisers in only two out of the six cases. ${ }^{29}$ In the remaining four cases, the Court ruled that the Commission applied the legal test correctly, both from a procedural (i.e. based on the reasons given by the Commission) and a substantive point of view (i.e. based on the Commission's assessment of the proposed Initiative's subject matter vis-à-vis Article $4(2)(b))$.

Yet, even in the cases where the applicants failed, the CJEU has clarified certain procedural aspects relating to the interpretation of Article 4(2)(b) of the ECI Regulation. This section distils the main findings of the CJEU with regard to three core procedural elements of the test: the responsibilities of the Commission and the responsibilities of the organisers during the registration phase, as well as the possibility to allow an Initiative to be partly registered. It illustrates the effects of the judgments on the practice of the Commission so far, and takes a step forward by considering the implications of the codification of partial registration in the Commission's New Proposed ECI Regulation.

\section{A. The responsibilities of the Commission and the ECI organisers}

A number of the cases before the CJEU had challenged the Commission's decisions on procedural grounds, arguing that the Commission had breached its duty to give reasons by inadequately justifying its rejections, or had misinterpreted the ECI Regulation by prohibiting the partial registration of proposed Initiatives. Consequently, some of the ECI-judgments dealt with the tasks of the Commission during the process of registering an ECI. For example, the ECJ in the appeal of the first ECI-case, namely Anagnostakis v Commission, analysed the Commission's tasks at the legal admissibility test both vis-a-vis Article 4 of the ECI Regulation, and in light of the principle of good administration. ${ }^{30}$ In this regard, the Commission is bound 'to conduct a diligent and impartial examination' of each proposed Initiative, which should take into consideration all the relevant features of the proposal. ${ }^{31}$ The

\footnotetext{
${ }^{28}$ For a recent article on the ECI case law see M. Inglese (n 6).

${ }^{29}$ See the cases of Minority Safe Pack and Efler.

${ }^{30}$ See paras 44-50; See also Minority SafePack para 32.

${ }^{31}$ Anagnostakis, ECJ para 47. See also Recital 10 of the ECI Regulation, which stipulates that the decision on the registration of a proposed Initiative must be in line with the principle of good administration.
} 
ECJ spoke of a 'duty' bestowed on the Commission 'to provide assistance and advice to the organisers of an ECI, in particular with regard to the registration criteria' ${ }^{32}$

While the ECJ referred to Recital 4 and Article 4(1) of the ECI Regulation as the foundations of the Commission's duty, a closer look into these provisions shows a more nuanced image of the Commission's role than that of having a 'duty to assist'. Recital 4 states that the Commission shall provide citizens with information and advice 'upon request' and Article 4(1) requires the Commission to provide information and assistance 'through a point of contact'. The Commission considers that it has fulfilled this duty by assisting interested citizens through the 'Europe Direct' centres and via technical support at the signature collection stage. ${ }^{33}$ Nevertheless, the language of the ECJ in Anagnostakis points to a stricter duty governing the Commission's activities at the registration stage with the purpose of ensuring easy accessibility to the ECI. ${ }^{34}$

Provided that the Commission acts upon this stricter duty to help potential organisers at the registration duty, the ECJ's proclamation on this aspect of the ECI's registration stage is good news for future ECI organisers. In fact, it tackles one of the main areas in need of improvement that were identified in the 2017 public consultation on the ECI viz. the need to provide enhanced advice and support to organisers regarding registration requirements. ${ }^{35}$ Rather independently from the judgment as such, there are already signs by the Commission of attempting to improve this element of the ECI. For instance, the Commission has procured the creation of a collaborative platform, where former ECI organisers are meant to interact with potential ECI organisers in order to provide advice and support. The collaborative platform is currently at a pilot stage but the Commission has recommended turning it into a permanent tool offering advice by including it in the Proposed New ECI Regulation. ${ }^{36}$

An additional development resulting from the ECI cases relates to the duty of the Commission to look at all the information provided by ECI organisers before concluding its assessment of a proposed Initiative. This point was one of the issues of disagreement between the Commission and ECI organisers in the cases of Iszak and Dabis and Minority SafePack. In the latter case, the organisers contested the lack of an explanation by the Commission as to which of the eleven acts proposed by their Initiative failed to comply with Article 4(2)(b) of the ECI Regulation and as to why this was so. They argued that the Commission infringed Article 296(2) TFEU (i.e. the obligation of EU institutions to state the reasons behind their legal acts) and Article 4(3) of the ECI Regulation, which states that the Commission shall inform the ECI organisers of the reasons for the refusal of their Initiative. ${ }^{37}$

\footnotetext{
${ }^{32}$ Anagnostakis, ECJ para 46.

${ }^{33}$ See Report from the Commission to the European Parliament and the Council on the application of Regulation (EU) No 211/2011 on the citizens' initiative Brussels, COM(2015) 145 final pp 13-14.

${ }^{34}$ Anagnostakis, ECJ para 49.

${ }^{35}$ Commission Staff Working Document (n 4) p 20.

${ }^{36}$ Article 4(2); The pilot version of the platform is accessible at <https://collab.ec.europa.eu/wiki/eci/display/ECI/European+Citizens\%27+Initiative+Forum>.

${ }^{37}$ Minority SafePack paras 8-12. The organisers had submitted an additional document with specific ECI proposals for the purpose of registering their Initiative.
} 
In contrast, the Commission's position was that its decision stated the main reasons for refusing the registration thus addressing the issues with the subject matter of the ECI as that was expressed by the ECI organisers in the registration form submitted to the Commission. Any additional information provided by the organisers to the Commission at the registration stage was only indicative and informative, and could not be seen as expanding or limiting the subject matter of the proposal. ${ }^{38}$

Dismissing the Commission's argument, the General Court in Minority Safepack reiterated its ruling in Iszak and Dabis that the Commission should have considered the information provided in the organisers' Annex as being equally important to the mandatory information required by Annex II of the ECI Regulation. Annex II of the ECI Regulation gives the possibility to the organisers to submit to the Commission additional information about their proposal, and has the same binding force as the ECI Regulation. Hence, the Commission has a duty, in accordance with the principle of sound administration, to consider all additional information in the same way as it considers the mandatory information required by Annex II. $^{39}$

Although these findings of the Court may come across as trivialities or as minor details in the grand scheme of things, they shape the extend of the Commission's duty to give reasons for rejecting an ECI. The expansion of the list of sources that should be taken into account at the registration stage implies an expanded legal duty to provide reasons for rejecting an ECI. According to the CJEU, the Commission's replies must include the reasons behind the refusal of an ECI in light of all the information submitted by the ECI organisers, and not just based on the subject matter stated in the registration form. ${ }^{40}$ This is a beneficial development not only for the clarity of the reasons behind the rejection of specific ECIs, but also because it acknowledges the organisers' efforts to put together a legally sound Initiative proposal.

Beyond the specific issues with the Annexes of a proposed Initiative, the case law also sheds light on the Commission's duty to give reasons more generally speaking. In this regard, the CJEU followed a line of thought consistent with the case law on the EU institutions' duty to give reasons under Article 296 TFEU. In the cases challenging the Commission's reasons for the refusal to register an ECI, the CJEU repeated the established line of case law on the EU Institutions' obligation to give reasons: the reasoning must allow the persons concerned to ascertain the reasons behind the measure, and should enable the competent Court to review

\footnotetext{
${ }^{38}$ Minority SafePack paras 13-14.

${ }^{39}$ Minority SafePack para 32; This was confirmed by the ECJ in Anagnostakis, ECJ, para 45.

${ }^{40}$ This was stressed by the General Court in Izsák and Dabis, Minority, and by the ECJ in Anagnostakis. In the case of Minority Safepack, for example, the General Court ruled that the Commission's reply, which only set out three short reasons for the refusal to register the proposal, was manifestly inadequate. According to the Commission's decision refusing the ECI, firstly, Article 2 TEU was not a legal basis for the adoption of the legal acts suggested by the ECI despite the reference, in that provision, to the rights of persons belonging to minorities as one of the values of the EU. Secondly, Article 3(3) TEU and Article 21(1) of the Charter cannot be used as a legal basis for EU action. Thirdly, although some of the acts requested in the Annex to the ECI could fall within the framework of the Commission's powers, the ECI Regulation does not provide for the registration of part or parts of a proposed Initiative. It should be noted here that the additional documents submitted by the organisers had proposed twenty legal bases for the proposed actions.
} 
the Institution's decision. ${ }^{41}$ At the same time, the reasons must be assessed with regard not only to the wording of the decision, but also taking into consideration the context of the case and the applicable legal rules. ${ }^{42}$

It is notable that in the ECI cases the Court did not deviate from the case law on Article 296 TFEU. It could be argued that, since these cases were the first ones concerning the ECI, the Court had some space to shape the Commission's duty to give reasons more closely in line with the ECI's objectives, as those are stipulated in primary (Article 11(4) TEU) and secondary (the ECI Regulation) EU law. For instance, the ECI's anchoring in the Treaty's provisions on democratic principles (Articles 9-12 TEU) could have called for a more open line of communication between citizens who wish to bring an ECI and the Commission than in other situations involving exchanges between citizens and EU Institutions.

The above comment is not meant to criticise the CJEU's approach to the issue per se. It is rather to question whether a modified duty to give reasons would not have accommodated also considerations relating to the inexperience with EU law of lay citizens who wish to bring an ECI. As will be discussed below, the CJEU did not consider the level of knowledge or experience of ECI organisers as an element that must be taken into account by the Commission during the examination of an Initiative's legal admissibility. ${ }^{43}$ In other words, the argument that most of the potential ECI organisers are lay citizens without EU law expertise cannot affect the strictly legal assessment that takes place during the legal admissibility test. With this consideration in mind, it can be argued that a stricter duty to give reasons would have been an alternative way to incorporate a particularity of the ECI in the relevant case law on the duty to give reasons.

The approach of the CJEU to assessing the reasoning of the Commission has also delineated the ECI organisers' duties at the legal admissibility stage. It has become evident from the ECI case law that the Commission is not the only actor with responsibilities at the registration stage. Instead, organisers also have responsibilities when providing the Commission with information at the registration stage. For example, regarding an Initiative proposing action on the basis of Article 352 TFEU, the General Court indicated that potential ECI organisers should not be criticised if they have not managed to establish the necessity of the act they are proposing. That assessment is, in any case, something that should take place after the registration of the ECI, even though it constitutes part and parcel of the competence stipulated in Article 352 TFEU. $^{44}$ The organisers should still demonstrate, however, that their proposal intends to attain a Treaty objective, which will allow the Commission to assess their request to use Article 352 TFEU as a legal basis. ${ }^{45}$

Along the same lines, organisers who only make general references to Treaty provisions without explaining the connection between the provisions and their ECI proposal should not

\footnotetext{
${ }^{41}$ Interporc v Commission, C-41/00 P, EU:C:2003:125, para 55.

${ }^{42}$ Elf Aquitaine v Commission, C-521/09 P, EU:C:2011:620 para 105; Club Hotel Loutraki and Others $v$

Commission, C-131/15 P, EU:C:2016:989, para 47.

${ }^{43}$ See below Section IV.B.

${ }^{44}$ The use of Article 352 TFEU as a legal basis to propose an Initiative is further discussed in Section IV.

${ }^{45}$ Constantini paras 53 and 78.
} 
expect from the Commission a fully detailed analysis of all the various Treaty provisions generally mentioned in the ECI proposal, and of why these could not be the basis for registration. ${ }^{46}$ Instead, the Commission is entitled to take a decision only based on the Treaty provision that was the least irrelevant to the objective of the proposed Initiative. ${ }^{47}$ Hence, in these situations, organisers should have limited expectations as to the reasons given by the Commission for the refusal of their ECI.

In principle, the above developments to the ECI's legal admissibility test have left us with a more flexible and user-friendly procedure for the registration of an Initiative than the initial stages of the ECI Regulation. In practice, the Commission has started publishing more detailed Decisions on the registration or refusal of every ECI that is submitted for registration instead of only sending a letter to organisers of Initiatives that were refused registration. This shift in the Commission's behaviour can be perhaps indirectly linked with the CJEU's jurisprudence on the extent of the Commission's duty to give reasons in the context of an ECI. It is also worth mentioning that the new Decisions on registered ECIs include a provision where the Commission explains its own understanding of the Initiative that it registers. This was not the case before. It used to be the case that an Initiative was simply registered, and its subject matter and objectives were fully discussed at the follow-up stage. ${ }^{48}$

The discussion so far has outlined the way in which the CJEU has clarified certain matters of contention between the organisers and the Commission regarding the application of the ECI legal admissibility test, and particularly the responsibilities of actors involved in the registration process. In what follows, we turn to the contribution of the CJEU to a third procedural aspect of the test, namely the possibility to partially register an ECI in cases where not all of the Initiative's objectives are fully compliant with the legal admissibility test.

\section{B. Partial Registration of an ECI}

The issue of whether the Commission can allow for the partial registration of an ECI was put before the General Court in the case of Minority Safepack. One of the grounds for review put forward by the applicants in the case was that the Commission infringed the procedural requirement to give reasons, inter alia because it failed to explain its position that the ECI Regulation does not allow for the registration of at least a part or parts of a proposed ECI. According to the letter sent to the organisers of Minority Safepack, some of the acts requested in the Annex to the ECI could fall within the framework of the Commission's powers, but the ECI Regulation prevented the registration of a part or parts of a proposed Initiative. This specification was not explicitly stated in the ECI Regulation and thus was criticised as needlessly restricting the scope of the proposed Initiatives and limiting the possibility for ECIs to generate public debate. ${ }^{49}$ The Commission's counter-argument in the case was that it

\footnotetext{
${ }^{46}$ Anagnostakis, para 31.

${ }^{47}$ See Anagnostakis, ECJ, para 38; Anagnostakis, paras 30-31.

${ }^{48}$ The ECI Register (n 8) allows for a comparison between older and more recent ECI registrations and refusals.

49 J Organ (n 5) p 432.
} 
was not obliged to explain the reasons behind its position that Article 4(2)(b) of the ECI Regulation does not allow partial registration of an ECI. ${ }^{50}$

Notably, the General Court did not rule on the point of partial registration. It merely found that the Commission's reasoning in the case was inadequate. The lack of sufficient reasoning impeded the organisers from re-submitting a new ECI proposal, as they did not have enough information about the types of acts that would have been accepted by the Commission. It also prevented the General Court from assessing the legality of the Commission's response. At a more general level, the lack of a complete statement of reasons discouraged citizens' participation in democratic life and contradicted the objective of the ECI to make the EU more accessible to citizens. ${ }^{51}$ The General Court therefore did not examine whether the Commission's interpretation of the ECI Regulation, which was not specified anywhere in the ECI legal framework, was legally sound. In the Court's view, it was unnecessary to rule on this question because the Commission had anyway failed to comply with its obligation to state reasons.

Despite the silence of the General Court on the matter of partial registration of an ECI, the judgment has led to a change to the subsequent approach of the Commission. ${ }^{52}$ After the General Court's judgment, the Commission made a 180-degree turn and started registering only parts of proposed ECIs that would otherwise have been rejected altogether. The first example of this change in practice is the Minority SafePack Initiative itself. Following the judgment, the Commission issued a new Decision on the same, initial proposal. The Decision sets out the eleven acts that were proposed by the Initiative's organisers, followed by a description of some (generic) areas in which legal acts can be adopted by the EU, which is meant to explain the framework of the Commission's powers to submit a proposal for an ECI in accordance with Article 4(2)(b) of the ECI Regulation. ${ }^{53}$ In turn, the Decision specifies which two proposals (out of the eleven proposals of the Initiative) do not satisfy Article

\footnotetext{
${ }^{50}$ Minority SafePack paras 13-14.

${ }^{51}$ Minority SafePack paras 28-29. It is also worth mentioning here that, in the remaining cases contesting the reasons given by the Commission for the rejection of Initiatives, the CJEU found that the Commission had not breached its duty to give reasons.

${ }^{52}$ The new Decision of the Commission on the Minority SafePack ECI states that '(i)n order to take the necessary measures to comply with the judgment of the General Court, a new Commission Decision on the request for registration of the proposed citizens' initiative has to be adopted'. This sentence is linked with the part of the judgment whereby the General Court stated that the Commission failed to comply with its obligation to state reasons, and not necessarily with the matter of partial registration. Commission Decision of 29.3.2017 on the proposed citizens' initiative entitled "Minority SafePack - one million signatures for diversity in Europe" Brussels, C(2017) 2200 final (hereinafter 'Commission Decision on Minority SafePack').

${ }^{53}$ Commission Decision on Minority Safepack (n 52) Recitals 4,5 and Recital 6 which states: 'For those reasons, the proposed citizens' initiative, inasmuch as it aims at proposals from the Commission for legal acts of the Union (...)', leaving to the reader the task of connecting the objectives of the proposed Initiative (Recital 4) with the explanation of the areas in which legal acts can be adopted (Recital 5). A new challenge was launched before the General Court (and is currently pending) against the reasoning of this Decision, see Romania $v$ Commission, Case T-391/17. Strikingly, the case is brought from Romania, and not from the organisers as such. At the moment we do not have any further insights as to the reasons for this. It does raise questions, however, concerning the involvement of a Member State - or Member State's authorities in a case concerning an Initiative brought by a group of private citizens.
} 
4(2)(b). As a result, the Commission registers only the remaining nine proposals of 'Minority SafePack'. According to the Decision, signatures supporting the Minority SafePack Initiative should be collected only to the extent that the said ECI aims at proposals from the Commission regarding the nine admissible parts of the ECI. ${ }^{54}$

Allowing the partial registration of ECIs is a positive development to the ECI's legal admissibility test, and to the ECI's future development. It allows for an increase in the pool of future ECIs, as Initiatives will no longer be rejected on this ground. The potential of this change to the test is evidenced by the Minority SafePack ECI itself: the ECI organisers recently announced that they have reached the necessary one million signatures, meaning that their ECI will most probably proceed to the so-called 'follow-up stage'. 55 Had the Commission followed its initial approach, which precluded partial registration of an ECI, 'Minority SafePack' would have remained in the list of the proposals that were rejected registration. It seems, however, that the Commission has not only changed its current practice based on the CJEU's judgment. A look at the Proposed New ECI Regulation indicates that the Commission acknowledges the advantages of partial registration, by proposing its codification.

\section{Looking forward: Partial registration under the Proposed New ECI Regulation}

Article 6 of the Proposed New ECI Regulation features a slightly modified ECI admissibility test than the current one, which repeats the basics of the current procedure: organisers can start collecting signatures supporting their ECI after they have submitted their request through the register and the Commission has checked that the proposal satisfies certain legal and procedural criteria and has registered the proposal. ${ }^{56}$ Article 6(3)(d) and (e) preserve two of the legal criteria of the current ECI Regulation: a proposed Initiative will not be registered if it is manifestly abusive, frivolous or vexatious, or if it is manifestly contrary to the values of the EU. ${ }^{57}$

The most prominent changes in comparison with the current Article 4(2)(b) of the ECI Regulation are included in Articles 6(3)(c) and Article 6(4) of the New ECI Regulation. Article 6(3)(c) states that the Commission shall register a proposed initiative if "none of the parts of the initiative manifestly falls outside the framework of the Commission's powers to submit a proposal for a legal act of the Union for the purpose of implementing the Treaties'. This provision should be read in conjunction with Article 6(4), which allows for the partial registration of an ECI by the Commission. The attempt to formalise partial registration is

\footnotetext{
${ }^{54}$ Commission Decision on Minority SafePack (n 52) Recital 9 and Recital 12. For other examples of partial registration see: Commission Decision of 4.7.2017 on the proposed citizens' Initiative "Stop TTIP" C(2017) 4725 final; and, Commission Decision of 22.3.2017 on the proposed citizens' Initiative "EU Citizenship for Europeans" COM(2017) 2001 final.

${ }^{55}$ According to the ECI's webpage, the organisers collected 1215876 signatures. These have not yet been submitted to the Commission. See <http://www.minority-safepack.eu/>.

${ }^{56}$ Article 6(1), (3), and (4) of the New ECI Regulation Proposal (n 4).

${ }^{57}$ See Article 4(2)(c) and (d) ECI Regulation.
} 
laudable from the point of legal certainty, although perhaps also unnecessary: there is nothing in the current ECI Regulation to prohibit the partial registration of an Initiative.

It can be argued that the current proposal for the New ECI Regulation, as described above, risks overcomplicating the registration process. The revised procedure consists of a back-andforth exchange of proposals between the Commission and the ECI organisers. If the Commission considers that only parts of a proposal fall within its competences to propose a legal act, it will send the proposal back to the organisers within one month, together with the reasons behind its assessment. It then becomes the responsibility of the organisers to change and resubmit, to maintain, or to withdraw their initial proposal. ${ }^{58}$ If the organisers decide to modify their proposal, they become responsible for submitting the necessary amendments to the Commission within one month. After receiving the amendments, the Commission has one month to assess the new information and to register, partially register, or reject the ECI. ${ }^{59}$

From a substantive point of view, the Commission would have to check if 'a substantial part of the initiative, including its main objectives' does not manifestly fall outside the framework of the Commission's powers to submit a proposal for a legal act. The proposed Regulation, however, does not clarify what is a 'substantial part' of a proposed Initiative: does it mean the most important proposals, more than half of the proposals, or simply 'the gist' of an Initiative? Does it formalise the Commission's current approach to partial registrations or does it signal a new way to tackle this issue? The lack of a clear explanation of what is a 'substantial part of the initiative' risks complicating the process and leading to disagreements between the Commission and organisers.

The Draft European Parliament Legislative Resolution on the Proposed New ECI Regulation rightly suggests a less complicated terminology. ${ }^{60}$ It recommends that the Commission should simply 'partially register the initiative if part of the initiative does not manifestly fall outside the framework of the Commission's powers to submit a proposal for a legal act of the Union for the purpose of implementing the Treaties' (Article 6(4)). ${ }^{61}$ It also suggests to extend by one month the timeframe for the organisers to amend their Initiative after the initial assessment of the Commission, and to give further details about the obligation of the Commission to give reasons for the way it handles a proposed Initiative. ${ }^{62}$ It is to be hoped that the European Parliament's proposed amendments will prevail in the shaping of the New ECI Regulation, in order to prevent the risks of further complicating the registration process.

\section{ON SUBSTANCE: THE NATURE OF THE TEST AND THE SCOPE OF THE EUROPEAN CITIZENS' INITIATIVE}

\footnotetext{
${ }^{58}$ Admittedly, it is not very clear why organisers might want to maintain a rejected proposal, which would probably simply be rejected again by the Commission.

${ }^{59}$ Article 6(4) of the New ECI Regulation Proposal.

${ }^{60}$ Draft European Parliament Legislative Resolution on the proposal for a regulation of the European Parliament and of the Council on the European citizens' initiative (COM(2017)0482 - C8-0308/2017 - 2017/0220(COD)) Amendment 30.

${ }^{61}$ ibid

${ }^{62}$ Amendments 29, 31, and 32.
} 
In addition to the generic and procedural clarifications discussed above, the case law of the CJEU has also contributed to the development of the ECI from a substantive point of view. In this sense, the CJEU has clarified questions about the type of legal assessment that needs to take place under the said provision. Moreover, it has contributed to the delineation of the scope of the European Citizens' Initiative by ruling on the possibility to use Article 352 TFEU as a legal basis, and the use of the ECI to influence international agreements. As we will see, these developments have not only answered questions on specific contested refusals to register ECIs, but have also extended the legal scope of the ECI as a participatory instrument.

\section{A.The nature of the legal admissibility test}

One of the most contested substantive aspects of the ECI's legal admissibility test was the interpretation of the term 'manifestly outside the framework of the Commission's powers to propose a legal act' which is stipulated in Article 4(2)(b) of the ECI Regulation. Some academic commentators had defended the view that the criterion of 'manifestly outside' should relate to the flexibility of the Commission towards the application of the ECI legal admissibility test. ${ }^{63}$ In this sense, it was argued that proposed Initiatives should be refused registration only when their objectives clearly could not be achieved through the available legal bases. ${ }^{64}$ Others argued that the wording of Article 4(2)(b) suggested that the test did not require final legal conclusions; those should be taken only at the end of the process, after the public hearing of an ECI. ${ }^{65}$ Instead, the ECI legal admissibility test should encompass only a preliminary legal assessment of a proposed Initiative.

By way of contrast, the Commission's view was that the legal review carried out during the legal admissibility stage 'cannot be rough but must, on the contrary, be full in order to prevent the procedure from progressing ${ }^{66}$ if the Commission cannot propose the adoption of an act because of its lack of competence. Furthermore, the Commission maintained the position that the registration of a proposed Initiative depends on the type of considerations that should be examined before deciding upon the existence of a competence to propose a legal act. Accordingly, a proposed Initiative would be inadmissible on the basis of Article 4(2)(b) of the ECI Regulation if "none of the provisions of the Treaties which provide for the adoption of legal acts on the basis of a proposal from the Commission can serve as the legal basis for an act covering the subject matter of the proposed ECI. Such a situation is manifest where that conclusion does not depend on factual circumstances. ${ }^{97}$

In the case of Constantini, the General Court touched upon the nature of the test and the level of legal analysis that the Commission should conduct during the legal admissibility stage. Disagreeing with the position of the Commission, the General Court sided with the

\footnotetext{
${ }^{63}$ A Karatzia (n 5) p 522.

64 J Organ (n 5).

${ }^{65}$ D Szeligowska, E Mincheva, 'The European Citizens' Initiative - Empowering European Citizens within the Institutional Triangle: A Political and Legal Analysis' (2012) 13(3) Perspectives on European Politics and Society 270 p 277.

${ }^{66}$ Constantini para 13.

${ }^{67}$ Constantini para 12.
} 
applicants: the wording of Article 4(2)(b) requires the Commission to carry out an initial examination of the information that it has in front of it. A more comprehensive examination should only be carried out if the proposal is registered, and should be published at the followup stage. ${ }^{6}$ For the purposes of the legal admissibility test, the Commission only has to establish whether 'in relation to a proposed ECI, it is manifest that it will be unable to make a proposal for a legal act founded on that provision' (e.g. on Article 352 TFEU). ${ }^{69}$

Along similar lines, the case of Iszak and Dabis ${ }^{70}$, which was decided one month after Constantini, states that Article 4(2)(b) of the ECI Regulation requires 'an initial assessment [by the Commission] of the information at its disposal in order to determine whether the proposal in dispute does not manifestly fall outside the framework of its powers.' A more exhaustive assessment is required under Article 10(1)(c) of the ECI Regulation. ${ }^{71}$ The case, therefore, confirms that the test under Article 4(2)(b) of the ECI Regulation is whether 'the Commission was manifestly not entitled to propose the adoption of an act of the Union based on the articles of the Treaties, in particular those cited by the applicants in the proposal. ${ }^{72}$ The ECJ has confirmed this interpretation in the case of Anagnostakis $v$ Commission, which was the first ECI-case to reach the ECJ (on appeal). ${ }^{73}$

It is apparent from the case law that the CJEU has maintained a relatively sympathetic approach towards citizens wishing to submit an ECI proposal by acknowledging the preliminary character of the legal assessment under Article 4(2)(b). As a result, in principle, the Commission is left with less of a leeway to reject an ECI on the grounds of legal admissibility. Even so, the case law provides scant further insight as to the exact format or the precise meaning of the word 'manifestly' under Article 4(2)(b), or as to the flexibility of the Commission when applying the test. One aspect which it does clarify is whether the Commission should take into consideration the status of ECI organisers who have submitted proposals, and the fact that these citizens might be unaware of the specifics of EU law. In their view, the Commission should conduct a light review at the stage of registration, merely to ascertain whether the proposed ECI is a matter on which citizens can exchange views with the EU institutions. ${ }^{74}$

The General Court did not examine the arguments concerning the background of the organisers or their capacity to put together a legally sound proposal. Instead, it observed that the aim of the ECI mechanism is not to initiate 'a mere dialogue between the citizens and the

\footnotetext{
${ }^{68}$ Constantini paras 14-17.

${ }^{69}$ Constantini para 53.

${ }^{70}$ The case challenged the refusal to register an Initiative called 'Cohesion policy for the equality of the regions and sustainability of the regional cultures'.

${ }^{71}$ Paras 60-61.

72 Para 61

${ }^{73}$ See para 50: 'It is only if a proposed ECI, in view of its subject matter and objectives, as reflected in the mandatory and, where appropriate, additional information that has been provided by the organisers pursuant to Annex II to Regulation 211/2011, is manifestly outside the scope of the powers under which the Commission may present a proposal for a legal act of the Union for the purposes of the application of the Treaties, that the Commission is entitled to refuse to register that proposed ECI pursuant to Article 4(2)(b) of that Regulation.'

${ }^{74}$ Constantini para 10.
} 
institutions', but to request the Commission to submit a proposal for a legal act. ${ }^{75}$ Hence, the legal admissibility test of Article 4(2)(b) is, above all, grounded in legal considerations based on the principles of conferral (Article 5 TEU) and institutional balance (Article 13(2) TEU). ${ }^{76}$ These are the yardsticks that should be used to interpret Article 4(2)(b), as opposed to an interpretation that takes into account the background of the Initiative organisers or their familiarity with EU law.

\section{B. The legal scope of the ECI}

As seen above, according to the Commission's interpretation of Article 4(2)(b) of the ECI Regulation the inadmissibility of an ECI is manifest when the Commission has to assess nonfactual circumstances to decide whether there is or not a Treaty provision allowing for a legal act on the subject matter of the proposed Initiative. ${ }^{77}$ Based on this interpretation, one might argue that the Commission should refuse the registration of a proposed Initiative if the suitability of a legal basis for registration depended on considerations that were not factual. For instance, the use of Article 352 TFEU as a legal basis could be problematic insofar as the use of that Treaty provision as a legal basis does not depend solely on factual circumstances, but rather requires an assessment of the necessity of the proposed measure. The provision gives the power to the Council, after obtaining the consent of the European Parliament, to adopt measures to attain one of the Treaty objectives if the Treaties have not provided the necessary powers (i.e. a lex specialis) and 'if action by the Union should prove necessary'. An assessment of this kind would probably entail political considerations by the EU institutions, which are not supposed to take place at the ECI legal admissibility stage. ${ }^{78}$

The General Court was given the opportunity to rule on the above point in the case of Constantini, where it was asked by the applicants to ascertain that Article 352 TFEU can constitute a legal basis for the registration of an ECI. The applicants argued that the Commission should have used Article 352 TFEU as the legal basis to register their (rejected) 'Right to Lifelong Healthcare Initiative. ${ }^{79}$ Moreover, they contended that citizens should not be obliged to show in their ECI proposals specifically how the adoption of a legal act would be necessary to attain the objectives of the Treaties. In their view, such a requirement would be contrary to the spirit of the ECI Regulation.

By virtue of the judgment, it is now clear that that 'neither Article 352 TFEU nor Regulation 211/2011 precludes recourse to Article 352 TFEU in the context of ECIs. ${ }^{80}$ According to the General Court, the conditions for recourse to Article 352 TFEU would still need to be satisfied at the point of registration, but the assessment of the necessity of a legal act should

\footnotetext{
${ }^{75}$ Constantini para 31.

${ }^{76}$ Constantini para 16.

${ }^{77}$ Constantini para 12.

${ }^{78}$ See M Dougan, 'What are we to make of the Citizens' Initiative?' (2011) 48 CMLRev 1807.

${ }^{79}$ Constantini para 10 . The initiative was proposing legislation that would guarantee access to long-term care services. An argument on the misinterpretation of Article 352 TFEU by the Commission was also made in the case of Izsák and Dabis but was found inadmissible by the General Court.

${ }^{80}$ Constantini para 52. For an engaging discussion on the use of Article 352 TFEU as a legal basis for an ECI, see M. Inglese (n 6).
} 
only take place after registration. The conclusions of this assessment should be published by the Commission at the follow-up stage, which is the final stage of a successfully submitted ECI.

It is worth noting that the Commission never stated that Article 352 TFEU cannot be used as a legal basis for the registration of an ECI. The Commission mentioned the Article only once, in its reply to the proposed 'Abolish Bullfighting Initiative', which proposed the prohibition of bullfighting in the EU. ${ }^{81}$ According to the Commission's statement, Article 352 TFEU was inadequate as a legal basis because of the objectives of the Initiative. The issue, therefore, seemed to be with the proposal itself, and not with using Article 352 TFEU as a legal basis.

Nevertheless, the General Court approached the question of Article 352 TFEU essentially by making a distinction between the legal and political considerations that must be taken into account in the ECI's lifecycle. The judgment sends the message that legal considerations regarding the competence to act on a proposed ECI should be separated from political considerations, such as the necessity of a proposal. The Court's approach is noteworthy when compares to the Treaty text, which neither distinguishes the two aspects of Article 352 TFEU, nor specified that necessity is a political decision as opposed to the (legal) decision of whether to use Article 352 TFEU as a legal basis. In this way, the Court seems to prefer an expanded interpretation of the ECI's scope, but also one that is in line with the ECI Regulation's underlying idea that, when it comes to the ECI, 'the legal' should be separated from 'the political'.

In 2017, the General Court further clarified the legal scope of the ECI in the Stop TTIP case. In fact, from a substantive point of view it is the latter case that has led to one of the most significant developments to the ECI admissibility test, by tackling the interpretation of the phrase 'legal acts for the implementation of the Treaties' for the purposes of registering an ECI. The Stop TTIP is the second case where the General Court annulled a Commission's Decision refusing registration of an ECI, and the first where it annulled a Commission's Decision on the substantive ground that the refusal to register the Initiative breached Article 11(4) TEU and Articles 2(1) and 4(2)(b) of the ECI. ${ }^{82}$ The essence of the issue in the case was whether limitations imposed by the Commission to the legal scope of the ECI were compatible with the applicable legal framework. These limitations were not explicitly set out

\footnotetext{
${ }^{81}$ The 'New Deal 4 Europe' ECI, which was registered but subsequently withdrawn by its organisers, also suggested Article 352 TFEU as a legal basis. However, since the ECI was not accompanied by a Commission's Decision, we cannot be sure as to which of all the proposed legal bases was approved by the Commission. ${ }^{82}$ This part of the article builds on a previous discussion of the case in A Karatzia 'New Developments in the context of the European Citizens' Initiative: General Court rules on 'Stop TTIP' EU Law Analysis, 18 May 2018, accessible at: <http://eulawanalysis.blogspot.co.uk/2017/05/new-developments-in-context-ofeuropean.html>. For commentary arguing that the Stop TTIP judgment is overall a welcome development for the ECI, see M Inglese, 'Positioning Efler in the Current Narrative of European Citizens' Initiatives' (2017) European Forum 1-10, and for commentary discussing the judgment vis-à-vis the TTIP negotiations see E Fahey, 'European Citizens Initiative "STOP TTIP” Can Proceed Says General Court' (2017) 8 EJRR 787-790. For an analysis of the case with regard to transparency and participation in EU external relations, see J Organ (n $6)$.
} 
in the ECI Regulation, but had derived from the Commission's interpretation of the ECI legal admissibility test.

The specific case before the General Court concerned an Initiative proposal to stop the TTIP and CETA agreements. ${ }^{83}$ At the time of the Initiative's proposal, the two agreements were at the forefront of the EU's actions in the field of external relations. In more detail, the proposed 'Stop TTIP' Initiative had invited the Commission to ask the Council to repeal its decision to authorise the opening of the TTIP negotiations under Article 218(2) TFEU. It also asked the Commission to submit a proposal for a Council decision not to conclude CETA. In September 2014, the Commission replied to the organisers that both their proposals had been rejected based on Article 4(2)(b) in conjunction with Article 2(1) of the ECI Regulation, because they fell outside the framework of the Commission's powers to submit a proposal for a legal act of the Union for the purpose of implementing the Treaties.

The reply to the organisers had revealed two limitations to the scope of the ECI. ${ }^{84}$ The first limitation imposed by the Commission was that an ECI could not invite the Commission to adopt preparatory acts that produce legal effects only between the EU and its Member States and between EU institutions. The Commission argued that its proposals to the Council under Article 218 TFEU to authorise the opening of negotiations for international agreements were not proposals for legal acts. Instead, the Council Decisions authorising the opening of negotiations for an international agreement are preparatory acts that produce legal effects only between the EU and its Member States and between the EU institutions. As a result, the Commission's relevant proposals to the Council lacked legal effect against third parties. In this sense, the position of the Commission was that 'Stop TTIP' was not proposing any legal acts for the purpose of implementing the Treaties and could not be registered.

The second limitation declared by the Commission was that an ECI could not invite the Commission to propose a decision not to adopt a legal act, such as a proposal not to conclude an international agreement, or to refrain from proposing a legal act for the conclusion of an international agreement to the Council. This proposal would lack any autonomous legal effect beyond the fact that the legal act in question would not be adopted.

The General Court widened the scope of the ECI by completely overruling the more limited Commission's interpretation of legal admissibility regarding proposals for the conclusion of international agreements under Article 218 TFEU. Perhaps the significance of this development was not so pronounced in the specific case at hand. The Court had already found that the concerned action in question (i.e. the decision to withdraw authorisation to open negotiations with a view to concluding the TTIP) was, in fact, not a preparatory act, but a definitive act, as it brings the said negotiations to an end. ${ }^{85}$ Moreover, the actions proposed by the Initiative fit neatly into the definition of a 'Decision' as a legal act under Article

\footnotetext{
${ }^{83}$ For brief descriptions of TTIP and CETA see: <http://ec.europa.eu/trade/policy/in-focus/ttip/about-ttip/> and $<$ http://ec.europa.eu/trade/policy/in-focus/ceta/> respectively.

${ }^{84}$ The letter sent from the Commission to the organisers is no longer available online. This is because, as will be explained later in the article, the Initiative was eventually registered through a new Commission Decision. For an analysis of the Commission's decision when it was first issued, see A Karatzia (n 5).

${ }^{85}$ Efler v Commission para 39.
} 
288(4) in the context of the conclusion of international agreements. ${ }^{86}$ Yet, in the judgment, the Court makes a more general point about the interpretation of Article 4(2)(b) of the ECI Regulation. It rejects a restrictive interpretation of 'legal acts', thus clarifying that the Commission cannot reject a proposed Initiative on the basis that the Initiative does not propose final EU acts with legally binding effects vis-à-vis third parties. ${ }^{87}$

In addition to expanding the definition of 'legal acts' in the ECI context, the judgment also clarified that citizens can utilise the ECI not only to ask for 'positive action' on behalf of the Commission, but also to ask for the partial or total repeal of legal acts. The Commission had argued that an Initiative proposing 'negative action' (e.g. the non-conclusion of an international agreement) contradicts the Commission's powers under Article 10(1)(c) of the ECI Regulation to issue a Communication setting out the 'action it intends to take, if any'. Based on this rather obscure argument, the Commission stated that a declaration on its behalf that, as a response to an ECI, it does not aim to propose the adoption of a legal act would have excessively limited the Commission's monopoly of legislative initiative. ${ }^{88}$

Contrary to the Commission's position, the General Court declared that a proposal for a legal act that implements the Treaties cannot be refused registration on the rationale that the proposal allegedly interferes with an ongoing legislative procedure or distracts the exercise of the Commission's monopoly of legislative initiative. ${ }^{89}$ In the case at hand, the act proposed by the Initiative aimed to prevent the conclusion of TTIP and CETA. These agreements would modify the EU legal order. A proposed legal act, such as the one in question, which seeks to prevent the modification of the EU legal order, contributes to the implementation of the Treaties, therefore fulfilling that part of the Article 4(2)(b) test. ${ }^{90}$

Before the Stop TTIP case, the Commission had limited the scope of ECIs to proposals giving a stamp of approval to an international agreement, and proposals to repeal an existing agreement, the argument being that only these 'positive' legal acts could be considered to implement the Treaties. The judgment now opens the door to ECI proposals concerning international agreements that are being negotiated at the time of the proposal's submission. It also opens the door to ECI proposals that object to the negotiations or the conclusion of those agreements. The significance of these possibilities, especially when it comes to the future use of the ECI to influence policy making at the EU level, is highlighted below.

\section{The possibility for registering ECIs in the field of international agreements}

The new developments in the ECI legal admissibility test have created the possibility for the instrument to be used in areas where this was not possible so far: the negotiation or the prevention of the conclusion of international (trade) agreements. The wide interpretation by the General Court of the notion of 'legal acts for the purposes of implementing the Treaties'

\footnotetext{
${ }^{86}$ Commission v Council, C-114/12, ECLI:EU:C:2014:2151.

${ }^{87}$ See para 35: "The concept of "legal act" cannot be understood "as being limited only to definitive European Union legal acts which produce legal effects vis-à-vis third parties".'

${ }^{88}$ Para 21.

${ }^{89}$ Paras 44-45

${ }^{90}$ Minority SafePack para 41.
} 
establishes the use of an ECI as a mechanism allowing citizens' participation and fostering a space for contention in areas where these elements traditionally lack a formalised outlet. ${ }^{91}$

This extension - or, perhaps, the calibration - of the ECI's legal scope to allow for the involvement of EU citizens in the conclusion of international agreements has come in good time: a time when citizens can have more insight than before into the negotiation process of such agreements. Some academics have argued that 'the TTIP marks the start of a new approach to transparency in trade negotiations that is very much to be welcomed. ${ }^{92}$ TTIP negotiations were accompanied by release of information to the European Parliament and the public, and were thought to signal 'a new generation of trade agreements ${ }^{\text {' }} 3$ characterised by an openness to debate, consultation, and the publication of EU's positions. ${ }^{94}$ This is not to say that TTIP is absolutely transparent or that the field of international agreements or external relations will automatically become more open to citizens' participation because of the increase in the transparency of the negotiations. ${ }^{95}$ Instead, it is to suggest that - at least in principle - this increased transparency in the process has the potential to enable citizens to participate more actively in the EU decision-making process.

With regard to the actual 'Stop TTIP' ECI campaign, it appears that the Court's judgment has had a limited impact. After the initial rejection by the Commission of their proposal in 2014, and while judicially challenging the Commission's approach, the organisers started a 'selforganised ECI', which attempted to collect signatures outside the ECI's legal framework. The campaign eventually collected more than three million signatures, which the organisers handed over to the Commission in October 2015. ${ }^{96}$ Between 2014 and 2017, several developments took place regarding TTIP and CETA, including 15 negotiating rounds on TTIP up to October 2016, and a proposal in July 2016 by the Commission to the Council for the signature and conclusion of CETA. ${ }^{97}$ CETA was signed in October $2016^{98}$, achieving the

\footnotetext{
${ }^{91}$ See J Organ (n 6) who explains that 'the negotiation of international agreements is a political role that has traditionally been the preserve of administrative and governing bodies, with little citizen or even parliamentary deliberative input.' p 1714. On the opposition by EU citizens to TTIP see H Pitlik, 'Who disapproves of TTIP? Multiple distrust in companies and political institutions' (2016) WIFO Working Paper 513

${ }^{92}$ M Cremona, 'Negotiating the Transatlantic Trade and Investment Partnership (TTIP)' (2015) 52 CMLRev 351; and the Commission's website on transparency in the context of the TTIP negotiations: <http://trade.ec.europa.eu/doclib/press/index.cfm?id=1230> .

${ }^{93}$ M Cremona (n 92) p 361.

${ }^{94}$ M Cremona (n 92); On the evolvement of the Commission's and the Council's position to transparency in the context of TTIP, questioning the real motives behind this move towards transparency, see J Organ (n 6) p 1724 onwards.

${ }^{95}$ On a critical discussion around transparency and legitimacy in EU policy-making see D Curtin, 'Does transparency strengthen legitimacy?' (2006) 11 Information Polity 109.

${ }^{96}$ See <https://stop-ttip.org/success-for-stop-ttip-3263920-million-signatures/>.

97 'EU-US Joint Progress Report on TTIP' January 2017 <https://ustr.gov/about-us/policy-offices/pressoffice/press-releases/2017/january/us-eu-joint-report-t-tip-progress-0>;

${ }^{98}$ Council Decision (EU) 2017/37 of 28 October 2016 on the signing on behalf of the European Union of the Comprehensive Economic and Trade Agreement (CETA) between Canada, of the one part, and the European Union and its Member States, of the other part (2016) OJ L 11/1.
} 
exact opposite of what the Stop TTIP organisers were asking through their ECI. This sequence of events meant that one of the basic goals of the Initiative has become redundant.

In 2017, the Commission reconsidered the 2014 proposal of the organisers, as a follow-up action to the annulment of its initial decision by the General Court. ${ }^{99}$ It registered the ECI only in so far as the campaign concerns the TTIP negotiations which are, in any case, currently frozen. The signature collection period for the ECI ended 10 July 2018, without any signs - online, at least, - that the campaign was actively collecting signatures. ${ }^{100}$ There are also no signs in the Commission's Decision that it might accept the previously collected 3 million signatures as fulfilling the signature quotas for the newly-registered Stop TTIP ECI.

Nevertheless, the impact of the development of the ECI legal admissibility test on international agreements signed by the EU go beyond the specifics of the Stop TTIP ECI. In particular, the CJEU's contribution may become relevant in the context of another, even more pertinent issue: Brexit. There have already been four proposed Initiatives linked with Brexit. Two of them were rejected by the Commission: 'Stop Brexit' and 'British friends-stay with us in EU'. The others, namely 'EU Citizenship for Europeans: United in Diversity in Spite of jus soli and jus sanguinis', 'Retaining European Citizenship', and 'European Free Movement Instrument' did not manage to reach one million signatures. ${ }^{101}$ Of these registered ECIs, the former ECI suggested the prevention of the Brexit process altogether, while the other three proposed actions to safeguard citizens' rights during the Brexit process. As such, these particular examples are not directly linked with acts for the conclusion of an international agreement (Article 207 and 218 TFEU), which were the bone of contention in the Stop TTIP case. ${ }^{102}$ They do illustrate, however, that some citizens have turned to the ECI as a means to try to influence the Brexit negotiations.

It is not unlikely that, in the future, we might see attempts to influence, through an ECI, the future agreement on the UK- EU relationship. Inevitably, for now this argument is speculative and assumes that an agreement between the UK and the EU will be negotiated on the basis of Article 107 and 218 TFEU after the withdrawal of the UK from the European Union.

Despite its speculative nature, it is worth entertaining for a moment the possibility of using an ECI in the upcoming Brexit negotiations and the way in which this can create a new

\footnotetext{
${ }^{99}$ Commission Decision on the registration of Stop TTIP (n 54).

100 The website of the ECI appears to be idle: <https://stop-ttip.org/>.

${ }^{101}$ For the details of these ECIs see the ECI Register: <http://ec.europa.eu/citizensinitiative/public/initiatives/open> For insightful commentary of the 'European Free Movement Instrument' ECI in light of Brexit see O Garner, 'The European Citizens Initiative on a European Free Movement Mechanism: A New Hope or a False Start for UK Nationals after Brexit?' European Law Blog, 23 February 2017.

102 The ECI 'EU Citizenship for Europeans' mentions Article 218(3) TFEU in the attempt to propose a disentanglement of EU Citizenship from national citizenship. The Commission's Decision registering that ECI (see above $\mathrm{n} 54$ ) does not refer to the provision. Instead, it registers the ECI only to the extent that it concerns the rights of third-country nationals residing legally in a Member State 'and in particular conferring certain similar rights to those linked to citizenship of the Union on citizens of a state that has withdrawn from the Union pursuant to Article 50 TEU.'.
} 
dimension to citizens' participation and voice in the Brexit process at the EU level. First of all, it is notable that we have not seen something similar to a Citizens' Initiative at the national level after the 23 June 2016 EU Referendum. Petitions sent to UK Parliament and a Citizens' Assembly on Brexit, which took place in September 2017, might be considered participatory instruments along the same spirit as a citizens' initiative but at the same time different from it. ${ }^{103}$ For instance, even if a petition gets to be debated before UK Parliament, the petitioners are not necessarily invited to the debate, while a Citizens' Assembly was a one-off event that required the recruitment of citizens to participate in it. What is more, both of them take place at the national level instead of the EU level, and none of them are directly linked to EU citizenship in the way that the ECI is presented to be. ${ }^{104}$ Instead, the debate in the UK has largely centred around the democratic representation of citizens in the final Brexit agreement through their representatives in Parliament, or through a second referendum, rather than through other means of participation.

A successful ECI attempting to influence the future UK-EU future relations by supporting or preventing a future agreement would also be a first in terms of citizens participating in the negotiations at the EU level. In the context of the current Brexit negotiations, the Commission has attempted to emphasise what it deems to be a 'tailor-made approach to transparency' that ensures 'the maximum level of transparency during the whole negotiating process. ${ }^{105}$ In addition to enhancing the transparency of the process, there seems to already be one element of public participation in the field of Brexit negotiations at the EU level, in the form of bilateral meetings between Directors-General and organisations of self-employed individuals, or stakeholders such as European associations who can contribute to the negotiations by presenting their take on the EU-wide impact of the UK withdrawal. ${ }^{106}$ The Commission's Decision on the publication of information on these meetings refers to Article 11(1) and (2) TEU, which requires EU institutions to give citizens and representative associations the opportunity to make known and publicly exchange their views in all areas of Union action, and to maintain an open, transparent, and regular dialogue with representative associations and civil society. ${ }^{107}$

It is well known, however, that the top-down engagement with stakeholders by virtue of Articles 11(1) and 11(2) TEU is different in nature from the type of bottom-up participation

\footnotetext{
${ }^{103}$ For UK Parliament petitions on Brexit see <https://petition.parliament.uk/petitions?q=brexit\&state=open> For the citizens' assembly see <https://citizensassembly.co.uk/brexit/about/>

${ }^{104}$ In fact, a UK petition can only be signed by UK nationals or UK residents. For the link between ECI and EU citizenship, see Anagnostakis, ECJ, para 24.

${ }^{105}$ See the Commission's website on transparency in the Brexit negotiations:

$<$ https://ec.europa.eu/commission/brexit-negotiations/european-commissions-approach-transparency-article-50negotiations-united-kingdom_en> From the UK's side of the negotiations, see:

<https://www.gov.uk/government/collections/article-50-and-negotiations-with-the-eu>.

${ }^{106}$ European Commission, 'Stakeholder outreach concerning Article 50 negotiations with the United Kingdom' 13 March 2017, accessible at: <https://ec.europa.eu/info/news/stakeholder-outreach-concerning-article-50negotiations-united-kingdom-2017-mar-13_en >.

${ }^{107}$ Commission Decision of 25 November 2014 on the publication of information on meetings held between Directors-General of the Commission and organisations or self-employed individuals (2014) OJ L 343/19.
} 
that is supposed to take place through an ECI. ${ }^{108}$ Articles 11(1) and (2) are seen as codifying previous practices by the Commission, which were highlighted in the 2001 White Paper on Governance and aim at involving a number of organised actors (e.g. representative associations and civil society organisations) in the EU decision-making process for the benefit of improving the policy outcome of that process. ${ }^{109}$ By way of contrast, the ECI was introduced as a bottom-up participation mechanism that aims at directly involving the citizen in the EU's decision-making process. In this sense, the use of the ECI would indeed be an innovation for the Brexit negotiations.

Beyond the theoretical advantages of using an ECI to influence the future course of Brexit, opening this door to EU citizens also raises some questions. Once again under the caveat that we may not even see an ECI attempting to influence the future UK-EU agreement, one can look ahead and wonder how appropriate or suitable it would be to allow citizens of the remaining $27 \mathrm{EU}$ Member States to influence the Brexit negotiating process. Let us assume, for the sake of the argument and based on the current state of play on Brexit, that the UK has withdrawn from the EU, the transition agreement has expired on 31 December 2020, and the Commission has proposed the initiation of negotiations for the conclusion of an international agreement under Article 218 TFEU between the EU and the UK as a third country. ${ }^{110}$ On the basis of EU primary law (Article 11(4) TEU), an ECI can be brought by 'not less than one million citizens who are nationals of a significant number of Member States'. Furthermore, according to the current ECI Regulation, the signatories of an ECI shall come from seven EU Member States, while the organisers of an ECI 'shall be citizens of the Union. ${ }^{\text {,11 }}$

This would lead us to the following - perhaps paradoxical - situation: In post-Brexit EU, a group of citizens from Member States other than the United Kingdom, could bring an Initiative supported by signatures from citizens from Member States other than the United Kingdom to influence a process that concerns the future relationship of the United Kingdom with the EU. Of course, one could make the same argument as the one above about any international (trade) agreement that concerns the EU and a third-country. Yet, the roots of Brexit in UK citizens' sentiments of repatriating control and reclaiming sovereignty, as well as the attachment of sovereignty to nationhood, could be said to distinguish an ECI

\footnotetext{
${ }^{108}$ LB Garcia, 'How could the new Article 11 TEU contribute to reduce the EU's democratic malaise?' in M Dougan, NN Schuibhne, E Spaventa, Empowerment and Disempowerment of the European Citizen (Hart 2012) 261; C Marxsen, 'Participatory Democracy in Europe - Article 11 TEU and the Legitimacy of the European Union' in F Fabbrini et al (eds) What Form of Government for the European Union and the Eurozone? (Hart 2015) pp 151-169.

${ }^{109}$ Commission White Paper on European Governance (COM(2001) 428 final; Sabine Saurugger, _The social construction of the participatory turn: The emergence of a norm in the European Union' (2010) 49 EurJPolRes pp 471, 475.

${ }^{110}$ See Article 121 on the Transition Period in the 'Draft Agreement on the withdrawal of the United Kingdom of Great Britain and Northern Ireland from the European Union and the European Atomic Energy Community', TF50 (2018) 35 - Commission to EU27 19 March 2018.

${ }^{111}$ Article 3(1) and Article 7(1) ECI Regulation.
} 
concerning Brexit than an ECI concerning any other international agreement negotiated by the EU. ${ }^{112}$

The extent to which British citizens can use an ECI to influence the Brexit process is a related issue. Yet, whether this is an actual possibility for the future depends primarily on when the ECI Regulation will cease to apply to the United Kingdom. It might be the case that the ECI Regulation will become inapplicable in the United Kingdom from even before the beginning of the transition period, i.e. from March 2019. It recently transpired that UK Parliament is currently unclear on this point. Although MPs were under the impression that the ECI Regulation will not apply to the UK during the transition period, the Minister for the Constitution has taken the position that the ECI Regulation will apply in the UK during the implementation period under the Withdrawal Agreement and Implementation Bill. ${ }^{113}$ The House of Commons European Scrutiny Committee is currently awaiting clarification by the Minister on this matter. It would seem that, if the MPs are correct on this matter, the possibility for British citizens to influence the Brexit process through an ECI is already curtailed, as any Initiative that is registered now will have less than twelve months to collect the necessary one million signatures.

The discussion so far has analysed the most pertinent developments that have taken place to the ECI's legal admissibility test since the inception of the mechanism in 2012, thus outlining the evolution of the test in the last six years. Changes to the interpretation and application of the test have resulted from the CJEU's intervention (e.g. on the concept of 'legal acts') and the Commission's own revised approach to the test (e.g. on partial registration). We have also discussed some of the consequences in practice of the evolution of the ECI legal admissibility test, touching upon the question of whether the changes are able to transform the ECI to a more extensive and more effective instrument of public participation, or whether they are merely creating the misleading impression that the ECI was given fresh life. The subsequent section further engages with this question by evaluating some of the limitations to the developments discussed so far.

\section{THE NEED TO PROCEED WITH CAUTION}

In Stop TTIP, the General Court linked the interpretation of Article 4(2)(b) of the ECI Regulation not only with the principles of conferral or institutional balance, but also with 'the principle of democracy' and the ECI's objective of 'improving the democratic functioning of the European Union by granting every citizen a general right to participate in democratic life'. ${ }^{114}$ Throughout the judgment, the General Court relied extensively on the nature of the ECI as a democratic participation mechanism that intends to foster democratic dialogue and allow citizens to address the Commission. This is visible in the fact that the Court interpreted the notions of 'legal acts' and that of 'implementing the Treaties' not only on a joint reading

\footnotetext{
${ }^{112}$ On the background to Brexit see $\mathrm{K}$ Armstrong Brexit Time: Leaving the EU - Why, how and when? (CUP 2017), and the Common Market Law Review Special Issue on Brexit (2018) Volume 55(2/1).

${ }^{113}$ House of Commons European Scrutiny Committee Twenty-seventh Report of Session 2017-19, pp 27-32.

${ }^{114}$ Minority SafePack, paras 36-38, 46-48.
} 
of Article 11(4) TEU and the relevant provisions of the ECI Regulation, but also by referring to the fundamental principle of democracy as included in the Preamble to the Treaty and the EU Charter of Fundamental Rights when expanding the Commission's initial - and rather more limited - delineation of the ECI's legal scope. ${ }^{115}$

Using as a starting point the Court's view of the ECI as a means of granting EU citizens the right to participate in EU's democratic life, we should take a pause here to consider the above Brexit scenario, as well as the rest of the developments to the ECI's legal admissibility test, in light of the limitations of the mechanism, and particularly the limitations to the success of getting an Initiative acted on by the EU institutions at the end of the signature collection process.

Arguments relating to the ability - or inability - of the ECI to influence the EU law-making process ${ }^{116}$ mandate a nuanced response both to the possibility of using the ECI to influence International Agreements - including in the context of Brexit - and to the positive effects of the evolution of the legal admissibility test more broadly speaking. The issue of an ECI's follow-up stage has become, by now, the 'elephant in the room' when it comes to discussing the ECI as a participatory instrument. Even if an ECI manages to register without any problems, and completes a very successful signature collection campaign, at the end of the day the question is how will the EU institutions, and primarily the Commission, respond to the proposals of the organisers.

Take here as an example the Ban Glyphosate ECI, which was registered in January 2017, and managed to reach the necessary signatures within approximately five months. ${ }^{117}$ The ECI called for the Commission to take three actions: to propose to Member States a ban on glyphosate, to reform the pesticide approval procedure, and to set EU-wide mandatory reduction targets for pesticide use. It was registered by the Commission in January 2017, and submitted its 1,070,865 statements of support, collected from 22 Member States, in October 2017. Its public hearing took place in November 2017 and the Commission submitted its final Communication one month later. ${ }^{118}$ Meanwhile, the Commission had already submitted to the Member States a draft Implementing Regulation for the renewal of the approval of glyphosate for five years. The Regulation was approved by a qualified majority of Member States and was adopted in December 2017. ${ }^{119}$ In its response to the ECI, the Commission expressed its plans to support the second and third aim of the ECI. However, it also stated

\footnotetext{
${ }^{115}$ Efler v Commission, paras 35-45.

${ }^{116}$ See A.Karatzia (n 9), N. Vogiatzis (n 6).

${ }^{117}$ The full name of the ECI was 'Ban glyphosate and protect people and the environment from toxic pesticides. the process. According to one of the organisations supporting this campaign, 'the ECI was backed by a broad, pan-European coalition of 38 organisations from 15 countries, including Corporate Europe Observatory (CEO), Greenpeace, the Health and Environment Alliance (HEAL), Pesticide Action Network Europe (PAN-E), and WeMove.EU.' <http://www.greenpeace.org/eu-unit/en/News/2017/commission-rejects-StopGlyphosate-ECI/> . ${ }^{118}$ Communication from the Commission on the European Citizens' Initiative "Ban glyphosate and protect people and the environment from toxic pesticides" Strasbourg, 12 December 2017 C(2017) 8414 final.

${ }^{119}$ Interestingly enough, the draft Implementing Regulation was adopted on 12 December 2017, which is the same day as the publication of the Commission's reply to the ECI.
} 
that, based on the available information and a favourable scientific assessment on glyphosate by the European Food Safety Authority, it had 'no basis to submit to the co-legislators a proposal to ban glyphosate', essentially dismissing the main objective of the ECI. This is despite a non-binding Resolution adopted by the European Parliament in 2017, which called for a glyphosate phase-out by $2022 .^{120}$

Considerations regarding the follow-up of an ECI should also qualify the possibility of Initiative organisers using Article 352 TFEU as the legal basis for their proposed Initiative. It is not often when a legal act will be proposed on the lex generalis of Article 352 TFEU instead of a lex specialis, especially after the Treaty of Lisbon. ${ }^{121}$ What is more, in the (nowadays) rare occasion where the Commission might, indeed, propose a legal act to the Council, the text of Article 352 TFEU requires both a unanimous adoption of the legal act by the Council, and the consent of the European Parliament. Both of these hurdles make the eventual follow-up of an ECI based on Article 352 TFEU questionable. ${ }^{122}$

Having said that, it should also be noted that the legal admissibility test and the follow-up stage are, formally speaking, two different steps in the whole ECI procedure, the former taking place at the very beginning and the latter at the very end. The example of the judgment on Article 352 TFEU shows that the CJEU also makes this distinction. As we have seen, the CJEU allowed the use of Article 352 TFEU as a legal basis despite the improbability of it actually leading to a successful legislative proposal in practice. This example emphasises that, in the CJEU's judgments, considerations about the follow-up stage did not affect considerations about the legal admissibility test.

What is more, the distinction between the legal admissibility test and the follow-up test was recently highlighted both in the above-mentioned case of Stop TTIP and in One of Us, which is the first ever judgment concerning the Commission's duties at the follow-up stage of the ECI (Article 10(1)(c) of the ECI Regulation). When taken together, the two judgments paint a picture of the ECI as an instrument that exists in line with the principle of institutional balance by allowing the Commission to have the last word on the legal and political conclusions on the ECI, thus preserving the institution's monopoly of legislative initiative.

For instance, after defending the participatory democratic character of the ECI in the Stop TTIP case, the General Court landed the applicants and the readers of the judgment back to reality by explaining that, even if the Commission proposes the acts of the ECI to the Council and the Council adopts them, there is nothing preventing the EU institutions from subsequently negotiating and concluding new transatlantic free-trade agreements. ${ }^{123}$ More

\footnotetext{
${ }^{120}$ European Parliament resolution of 24 October 2017 on the draft Commission implementing regulation renewing the approval of the active substance glyphosate in accordance with Regulation (EC) No 1107/2009 of the European Parliament and of the Council concerning the placing of plant protection products on the market, and amending the Annex to Implementing Regulation (EU) No 540/2011 (D053565-01 - 2017/2904(RSP)).

${ }^{121}$ R Schütze, 'Organized Change towards and 'Ever Closer Union': Article 308 EC and the Limits to the Community's Legislative Competence’ (2003) 22(1) YEL 79.

${ }^{122}$ See also M. Inglese (n 6) pp 343-346.

${ }^{123}$ Efler $v$ Commission paras 45-48; On the ECI and the principle of institutional balance see A. Karatzia (n 9).
} 
explicitly, in the case of One of Us, the General Court clarified that the Commission is not required to submit a proposal for a legal act following an ECI. What happens at the ECI's registration stage does not bind the Commission as to its approach at the follow-up stage. ${ }^{124}$ The Commission's decision of whether or not to register an ECI involves only a first assessment of the legal aspect of the proposal and 'is without prejudice to the Commission's assessment in the context of the communication adopted on the basis of Article 10(1)(c)'. ${ }^{125}$

The implications of the distinction described here are seen in the actual One of Us judgment itself, where the General Court refrained from reviewing to any great length the Commission's final decision not to act on the proposals of the One of Us. Although the General Court examined in quite some detail whether the Commission fulfilled its (procedural) duty to give reasons, it only conducted a limited review of the applicant's argument that the Commission's assessment of the ECI was mistaken. Since the Commission has broad discretion in exercising its powers of legislative initiative, the final decision of the Commission regarding a successful ECI can only be reviewed by the CJEU to identify any manifest errors of assessment behind the decision. ${ }^{126}$ In light of the CJEU's approach, organisers who wish to contend the Commission's final decision on their successful ECI should bear in mind the inherent limitations that they will face if they follow the judicial avenue for this purpose.

Yet, one might ask whether recent procedural changes in the Commission's approach to the ECI registration stage might blur the line between deciding on legal admissibility of ECIs and deciding on their follow-up. We have argued above that, in principle, the legal admissibility test has become more flexible than in previous years. We have also identified a practical change in the attitude of the Commission in that it is now publishing its decisions to register proposed Initiatives. ${ }^{127}$ The more elaborate explanations of the Commission's decisions at the legal admissibility stage should provide a clearer picture to ECI organisers and stakeholders as to the Commission's position and the reasons behind the registration or rejection of each submitted Initiative. Despite its positive elements, however, the Commission's change in attitude bears the question whether the Commission's initial explanation of its own views on an Initiative may constrict the organisers' proposals at the end of a process by not allowing them to further develop their understanding of their proposals. After all, as we have seen, the ECI legal admissibility test should only be a preliminary test that leaves a full legal assessment for the end of the signature collection process.

\section{CONCLUSION}

The article has highlighted some of the positive current, but also potential, outcomes of the new developments in the context of the ECI's legal admissibility test and has illustrated some of the limitations to these developments. It has provided an updated view of the ECI's legal

\footnotetext{
${ }^{124}$ One of Us paras $116-117$.

125 ibid. See also Costantini, para 53.

${ }^{126}$ One of Us paras 168-170.

${ }^{127}$ See above, Section III.A.
} 
admissibility test in light of the CJEU's ECI-jurisprudence, and the Commission's past and current approach to the registration stage. Before concluding, it is worth explaining why the exercise of keeping track of, and evaluating the developments to, the ECI legal admissibility test is pertinent and timely.

Firstly, the reconsideration of the ECI legal admissibility test comes in good time. Legal challenges to the Commission's approach in the context of rejected Initiatives have given the CJEU the opportunity to clarify the existing legal framework viz. the registration stage, and more specifically Article 4(2)(b) of the ECI Regulation. In turn, the body of case law that arises from the CJEU's jurisprudence on the ECI has given us the opportunity to consider whether, and how, the ECI legal admissibility has developed since 2012.

Secondly, an analysis of the ECI legal admissibility test remains as relevant to the overall assessment of the ECI as it was when the ECI Regulation first came to life. To put it simply, the stricter the interpretation of Article 4(2)(b), the more limited the scope of the ECI will be, and the less the variety of acts that citizens will be able to propose. It holds true that the impact of the ECI legal admissibility test on the registration of Initiatives should not be exaggerated: the application of the test so far has not stopped the ECI from being used. Although the number of ECIs has decreased since the first three years of the ECI Regulation's application, there is no proof that the legal admissibility test should be solely blamed for this decrease. ${ }^{128}$ However, it is also true that the Commission's role as a 'doorstopper' at the registration stage of an Initiative is directly linked to the use of the ECI as a novel, democratic method for citizens to propose legislative or policy measures to the Commission and potentially to the EU legislators.

The pertinence of the ECI legal admissibility test in the ECI's functioning was also highlighted by the CJEU in the cases discussed in this contribution, albeit with some nuances among the judgments. For instance, the General Court in Anagnostakis and Constantini considered the legal admissibility test against an understanding of the ECI as a right attached to EU citizenship. According to the Court, the ECI expresses 'a right of Union citizens to submit a citizens' initiative', which is enshrined in Article 24(1) TFEU. A refusal to register a proposed Initiative is, therefore, an action that may 'impinge upon the very effectiveness' of the said right. ${ }^{129}$

The General Court also relied on the notion of democracy when interpreting the legal admissibility conditions, in the case of Stop TTIP. More explicitly, the Court stated that the aim of the ECI is 'to allow EU citizens to participate more in the democratic life of the European Union', in particular by presenting the ECI to the Commission and, during the public hearing to the Parliament, and requesting the Commission to submit a proposal for a legal act, stimulating simultaneously a democratic debate. ${ }^{130}$ The ECJ was less enthusiastic in

\footnotetext{
${ }^{128}$ For an overview of the ECI's use and the challenges faced by organisers since 2012, see Commission's 2018 ECI Report (n 2) and Commission Staff Working Document on a New ECI Regulation Proposal (n 4).

${ }^{129}$ Anagnostakis paras 25-26; Constantini para 72.

${ }^{130}$ Efler v Commission para 45.
} 
using the terminology of 'a right to submit a citizens' initiative'. Instead, in the judgment on appeal of Anagnostakis, it presented the ECI as:

'an instrument concerning the right of citizens to participate in the democratic life of the Union, provided for in Article 10(3) TEU, in that it allows them to apply directly to the Commission in order to submit to it a request inviting it to submit a proposal for a legal act of the Union, for the purposes of the application of the Treaties ${ }^{131}$

and explained that Article 4(2)(b) is a precondition for citizens to do so. This is not the place to delve into whether the Treaties bestow a right to citizens through an ECI, or what the limitations of that right are. For our purposes, it suffices to say that the ECI-judgments confirm our understanding of the ECI legal admissibility test as a first port of call for Initiative organisers affecting the way in which - and the extent to which - EU citizens can take advantage of the ECI mechanism to suggest legislative or policy measures at the EU level.

This article has argued that the interpretation and application of the ECI legal admissibility test has evolved since 2012. This evolution has taken place primarily in two ways. On the one hand, certain contested procedural aspects of the ECI's legal admissibility test have been resolved, opening new doors for the use of the ECI, such as the potential to partially register an Initiative. On the other hand, the scope of the ECI has been extended. Citizens are now able to propose Initiatives objecting to the conclusion of an international agreement that is being negotiated by the EU, which was not the case before the CJEU's judgment in Stop TTIP. The analysis has illustrated the impact of the CJEU on the development of the test, by illustrating the way in which the CJEU filled certain gaps in our understanding of the ECI's legal admissibility test.

Finally, in anticipation of future ECIs on the expanded scope of the ECI vis-à-vis international agreements, this contribution reflected on the possibility of using the ECI to influence the post-Brexit agreement on the future relations between the UK and the EU. It was highlighted that anyone who considers bringing an ECI from this newly-opened gate should proceed with caution: the classic limitations to the follow-up stage of an ECI still exist, and there is a risk that the New ECI Regulation, if passed without amendments, might further complicate the process for registration. Ultimately, while acknowledging the positive contributions of the recent developments to the ECI's legal admissibility stage, the contribution expresses nuanced expectations of how these developments may play out in practice.

${ }^{131}$ Anagnostakis, ECJ, para 24. 